JPPKMI 2 (1) (2021) 17-25
JURNAL PENELITIAN DAN PENGEMBANGAN
KESEHATAN MASYARAKAT INDONESIA
Jttps://journal.unnes.ac.id/sju/index.php/jppkmi

\title{
Sanitasi Penyediaan Air Bersih dengan Kejadian Stunting pada Balita
}

\author{
Septi Khotimatun Nisa ${ }^{1}$, Elisabeth Deta Lustiyati ${ }^{1} \bowtie$, Ayu Fitriani ${ }^{1}$
}

${ }^{1}$ Program Studi Kesehatan Masyarakat Program Sarjana, Universitas Respati Yogyakarta, Indonesia

\section{Info Artikel}

Sejarah Artikel:

Diterima 8 April 2021

Disetujui 12 Juni 2021

Dipublikasi 16 Juni 2021

\section{Keywords:}

Sanitation, Clean Water,

Wells, Stunting

URL:

hhttps://iournal.unnes.ac id/siu/index.php/ippkm i/article/view/47243

\begin{abstract}
Abstrak
Angka kejadian stunting di Kecamatan Kalasan pada tahun 2018 sebesar 17,01\%, nilai tersebut masih jauh dari target penurunan stunting di Kabupaten Sleman yaitu 10\%. Penelitian ini bertujuan untuk mengetahui hubungan antara sanitasi penyediaan air bersih dengan kejadian stunting pada balita di Desa Tamanmartani. Penelitian ini menggunakan metode analitik dengan pendekatan kasus kontrol. Teknik pengambilan sampel menggunakan total sampling. Sampel penelitian ini adalah ibu yang memiliki balita, yaitu 45 kasus dan 45 kontrol. Instrumen diadaptasi dari formulir inspeksi sanitasi penyediaan air bersih dari Dinas Kesehatan Daerah Istimewa Yogyakarta. Analisis data menggunakan uji Chi-square. Hasil penelitian ini menunjukkan ada hubungan signifikan antara sanitasi penyediaan air bersih dengan kejadian stunting $(\mathrm{p}=0,047, \mathrm{OR}=2,705)$ Disarankan bagi masyarakat perlu membersihkan area sekitar sumur gali/ledeng dari kotoran hewan ternak dan sampah, menghindari genangan air serta perbaikan retakan sekitar sumur.
\end{abstract}

\section{Abstract}

Stunting incidence at Kalasan District in 2018 was 17.01\%, this value is still far from the target for reducing stunting in Sleman Regency, which is 10\%. This study aims to determine the relationship between sanitation of clean water supply and the incidence of stunting in children under five in Tamanmartani Village. This study uses an analytical method with a case-kontrol approach. The sampling technique used was total sampling. The sample of this study were mothers who had toddlers aged 0-59 months, there were 45 cases and 45 kontrols. The instrument adapted from the clean water supply sanitation inspection form from Yogyakarta Special Region Health Office. Data analysis using Chi-square test. The results of this study indicate that there is a significant relationship between sanitation of clean water supply and the incidence of stunting $(p=0.047$, $O R=2.705)$. It is recommended for the community to clean the area around the dug wells from livestock manure and garbage, avoid puddles of water and repair cracks around the well.

Alamat korespondensi:

JL. Laksda Adisucipto KM 6,3

Depok, Sleman, Yogyakarta

E-mail: elisabethdeta@respati.ac.id 


\section{PENDAHULUAN}

Dinas Kesehatan Kabupaten Sleman mempunyai target penurunan stunting tahun 2018 yaitu 10\%. Berdasarkan data Pemantauan Status Gizi (PSG) balita di Kabupaten Sleman tahun 2018 diperoleh angka kejadian stunting $11 \%$. Kecamatan Kalasan memiliki angka kejadian stunting lebih tinggi dari angka kejadian stunting di Sleman yaitu 17,01 \% (Dinas Kesehatan Kabupaten Sleman, 2018).

Kategori status gizi anak usia $0-60$ bulan termasuk pendek (stunted) jika $\mathrm{PB} / \mathrm{U}$ atau TB/U memiliki nilai Z-score berada pada nilai $3 \mathrm{SD}$ sd $<-2 \mathrm{SD}$, serta sangat pendek (very stunted) dengan nilai < -3SD (Kemenkes RI, 2020) Stunting pada balita adalah suatu kegagalan pertumbuhan yang berlangsung dalam jangka waktu lama pada anak di bawah lima tahun ketika tumbuh dengan keterbatasan akses terhadap makanan dan pelayanan kesehatan. Stunting juga dikenal sebagai kondisi kekurangan gizi kronis, stunting dapat mengakibatkan gangguan kognitif seperti keterlambatan perkembangan motorik dan gangguan fungsi otak (Initiatives, 2018). Stunting disebabkan oleh faktor multi dimensi, diantaraya faktor lingkungan. Faktor lingkungan yang menjadi penyebab kejadian stunting yaitu higiene personal ibu (Rah et al., 2015), sanitasi (Rahayu and Darmawan, 2019), air bersih (Adriany et al., 2021) dan sumber air minum (Irianti et al., 2019).

Faktor sanitasi yang tidak layak mempunyai hubungan signifikan dengan stunting, sehingga anak dengan kondisi sanitasi yang tidak layak mempunyai risiko 5,0 kali tebih besar mengalami stunting (Apriluana and Fikawati, 2018). Akses sanitasi yang layak dapat melindungi balita terhadap stunting sebesar $70,6 \%$ (Vilcins, Sly and Jagals, 2018). Air minum yang bersih dan memadai, sanitasi layak, saluran air untuk air limbah dan pengelolaan limbah padat yang tepat adalah intervensi kesehatan ekuitas yang utama (WHO, 2018).

Hasil penelitian Torlesse et al., (2016) diperoleh ada interaksi antara fasilitas sanitasi rumah tangga dan pengolahan air pada anak yang tinggal di rumah tangga yang minum air tidak diolah. Hasil penelitian tersebut, diperoleh risiko mengalami stunting lebih dari 3 kali lebih besar pada anak yang tinggal di rumah tangga menggunakan jamban yang tidak diperbaiki.

Kurangnya kebersihan dari air yang digunakan dalam sehari-hari menyebabkan terjadinya penyakit infeksi seperti diare dan kecacingan, sehingga balita akan mengalami gangguan penyerapan nutrisi pada proses pencernaan yang mengakibatkan berat badan balita akan turun. Penyakit infeksi yang berlangsung dalam waktu lama dan sering akan menyebabkan stunting pada balita (Kemenkes RI, 2018). Berdasarkan latar belakang di atas maka penelitian dilakukan dengan tujuan untuk mengetahui hubungan antara penyediaan sanitasi air bersih dengan kejadian stunting pada balita.

\section{METODE}

Penelitian ini menggunakan metode analitik dengan pendekatan kasus kontrol. Variabel bebas penelitian adalah tingkat sanitasi penyediaan air bersih dan variable terikat yaitu kejadian stunting. Penelitian dilaksanakan di Desa Tamanmartani Kecamatan Kalasan Kabupaten Sleman DIY pada 21 Mei - 14 Juni 2020. Populasi balita kasus dan kontrol dalam penelitian ini diperoleh dari data sekunder kejadian stunting tahun 2019 Unit Gizi Puskesmas Kalasan. Peneliti melakukan pengukuran ulang balita di lapangan dan diperoleh seluruh data stunting tahun 2019 tidak ada perubahan. Kriteria inklusi pada kasus dan kontrol adalah rumah dengan balita stunting dan tinggal menetap di Desa Tamanmartani.Teknik pengambilan sampel menggunakan total sampling. Sampel yang digunakan dalam penelitian ini adalah 90 dengan jumlah kelompok kasus (stunting) sebanyak 45 balita dan kelompok kontrol (normal) sebanyak 45 balita. Instrumen penelitian yang dipergunakan untuk pengukuran variabel bebas yaitu sanitasi penyediaan air bersih menggunakan formulir inspeksi sanitasi penyediaan air bersih dari 
Dinas Kesehatan Daerah Istimewa Yogyakarta. Skor total pengisian kuesioner dibagi menjadi 4 kategori yaitu sangat baik (skor 8-11), baik (skor 6-7), kurang baik (skor 3-5), tidak baik (skor 0-2)

\section{HASIL DAN PEMBAHASAN}

\section{Gambaran Karakteristik Responden}

Responden penelitian ini terdiri dari 45 responden kelompok kasus dan 45 responden kelompok kontrol diperoleh dari data sekunder Unit Gizi, Puskesmas Kalasan tahun 2018 diperlihatkan pada Tabel 1.

Tabel 1. Karakteristik Balita di Desa Tamanmartani

\begin{tabular}{lllll}
\hline \multirow{2}{*}{ Karakteristik balita } & \multicolumn{2}{l}{ Kasus } & \multicolumn{2}{c}{ Kontrol } \\
\cline { 2 - 5 } & $\mathrm{N}$ & $\%$ & $\mathrm{~N}$ & $\%$ \\
\hline Usia Balita (bulan) & & & & \\
$6-11$ & 1 & 2,2 & 2 & 4,4 \\
$12-23$ & 9 & 20 & 11 & 24,4 \\
$24-35$ & 16 & 35,6 & 10 & 22,2 \\
$36-47$ & 8 & 17,8 & 15 & 33,3 \\
$48-59$ & 11 & 24,4 & 7 & 15,6 \\
Total & 45 & 100 & 45 & 100 \\
Jenis Kelamin & & & & \\
Laki-laki & 21 & 46,7 & 24 & 53,3 \\
Perempuan & 24 & 53,3 & 21 & 46,7 \\
Total & 45 & 100 & 45 & 100 \\
\hline
\end{tabular}

Sumber : Data Sekunder Puskesmas Kalasan Unit Gizi, 2019.

Berdasarkan Tabel 1 karakteristik usia balita di Desa Tamanmartani sebagian besar balita stunting berusia $24-35$ bulan yaitu dengan jumlah 16 balita $(35,6 \%)$. Masa anak dibawah lima tahun (anak balita usia 12-59 bulan). Pada masa ini, kecepatan pertumbuhan mulai menurun dan terdapat kemajuan dalam perkembangan motorik (gerak kasar dan gerak halus) serta fungsi ekskresi. Periode penting dalam tumbuh kembang anak adalah pada masa balita. Pertumbuhan dasar yang berlangsung pada masa balita akan mempengaruhi dan menentukan perkembangan anak selanjutnya (Kemenkes RI, 2020). Menurunnya kecepatan pertumbuhan ini bersamaan dengan fase dimana balita masuk dalam masa penyapihan, pada masa penyapihan ada beberapa kemungkinan balita mengalami penurunan nafsu makan padahal pada usia ini balita sudah mulai bisa berjalan dan melakukan aktivitas lebih banyak untuk bermain. Sehingga kebutuhan zat gizi balita tidak terpenuhi (Illahi, 2017). Usia 24- 59 bulan merupakan masa golden age, apabila kebutuhan gizi yang tidak terpenuhi dapat menyebabkan gangguan pertumbuhan dan perkembangannya, sehingga balita yang kebutuhan gizinya tidak terpenuhi cenderung lebih kurus dan pendek dibandingkan dengan teman sebayanya yang kebutuhan gizinya terpenuhi (Khulafa'ur Rosidah and Harsiwi, 2019).

Sebagian besar balita stunting yaitu 24 orang atau 53,3\% memiliki jenis kelamin perempuan. Faktor internal yang mempengaruhi pertumbuhan salah satunya adalah jenis kelamin. Balita perempuan memiliki lebih banyak mempunyai jaringan lemak serta jaringan otot lebih sedikit dari balita laki-laki. Sehingga balita perempuan mempunyai resiko lebih besar mengalami stunting 0,8 kali dari balita laki-laki (Lalo, Tahu and Bara, 2018). Sejalan dengan penelitian (Illahi, 2017) menunjukkan bahwa balita perempuan lebih tinggi yang mengalami stunting dibandingkan dengan balita laki-laki. Serupa dengan penelitian (Sinatrya and Muniroh, 2019) mengemukakan bahwa mayoritas jenis kelamin balita yang mengalami stunting adalah balita perempuan.

\section{Sanitasi Penyediaan Air Bersih}

Gambaran sanitasi penyediaan air bersih pada penelitian ini meliputi kualitas air bersih parameter fisik, jenis sanitasi penyediaan air bersih, tingkat sanitasi penyediaan air dalam sampel penelitian.

Pada Tabel 2 terlihat jenis sanitasi penyediaan air bersih sumur pompa/ledeng lebih banyak digunakan oleh responden dibandingkan dengan sumur galiSumur termasuk dalam sumber air tidak terlindung. Air yang tidak terlindung dapat menyebabkan masalah kesehatan salah satunya adalah penyakit diare. Balita yang mengalami diare pertumbuhannya mengalami keterlambatan (Sinatrya and Muniroh, 2019).

Kualitas air bersih parameter fisik tidak 
Tabel 2. Karakteristik Sanitasi Air Bersih

\begin{tabular}{llllll}
\hline Karakteristik Sanitasi & \multirow{2}{*}{ Kategori } & \multicolumn{3}{l}{ Kasus } & \multicolumn{2}{l}{ Kontrol } \\
\cline { 3 - 6 } Air Bersih & & $\mathrm{N}$ & $\%$ & $\mathrm{~N}$ & $\%$ \\
\hline Jenis sumber air bersih & Sumur Gali & 21 & 46,7 & 21 & 46,7 \\
& Sumur Pompa/Ledeng & 24 & 53,3 & 24 & 53,3 \\
Kualitas fisik air bersih & Baik & 39 & 86,7 & 42 & 93,3 \\
& Tidak Baik & 6 & 13,3 & 3 & 6,7 \\
\hline
\end{tabular}

Sumber : Data Primer, 2020

Tabel 3. Distribusi frekuensi sanitasi penyediaan air bersih

\begin{tabular}{|c|c|c|c|c|}
\hline \multirow{2}{*}{ Indikator } & \multicolumn{2}{|l|}{ Ya } & \multicolumn{2}{|c|}{ Tidak } \\
\hline & $\mathrm{N}$ & $\%$ & $\mathrm{~N}$ & $\%$ \\
\hline Jarak jamban dari sumur minimal 10 meter & 72 & 80 & 18 & 20 \\
\hline $\begin{array}{l}\text { Jarak } 10 \text { meter di sekitar sumur tidak ada sumur pencemar lain, } \\
\text { misal kotoran hewan, sampah dan genangan air }\end{array}$ & 23 & 25 & 67 & 75 \\
\hline $\begin{array}{l}\text { Tidak ada genangan air pada jarak } 2 \text { (dua) meter di sekitar } \\
\text { sumur }\end{array}$ & 23 & 26 & 67 & 74 \\
\hline Saluran pembuangan air limbah ada & 79 & 88 & 11 & 12 \\
\hline Saluran pembuangan air limbah tidak rusak & 39 & 44 & 51 & 56 \\
\hline $\begin{array}{l}\text { Lantai semen yang mengitari sumur mempunyai radius lebih } \\
\text { dari } 1 \text { (satu) meter }\end{array}$ & 47 & 52 & 43 & 48 \\
\hline Tidak ada genangan air diatas lantai semen sekeliling sumur & 32 & 36 & 58 & 64 \\
\hline Tidak terdapat retakan pada lantai sekitar sumur & 20 & 22 & 70 & 78 \\
\hline Ember dan tali diletakkan pada tempatnya & 75 & 83 & 15 & 17 \\
\hline Bibir sumur sempurna tidak ada retakan & 66 & 73 & 24 & 27 \\
\hline $\begin{array}{l}\text { Dinding semen ketinggian } 3 \text { (tiga) meter dari atas permukaan } \\
\text { tanah diplester sempurna dan tidak ada retakan }\end{array}$ & 61 & 68 & 29 & 32 \\
\hline
\end{tabular}

Sumber : Data Primer, 2020

baik, terdapat pada responden stunting sebanyak 6 responden $(13,3 \%)$ dan responden normal sebanyak 3 responden $(6,7 \%)$. Faktor terbesar yang menyebabkan kualitas air bersih parameter fisik responden pada kedua kelompok tidak memenuhi syarat adalah air yang keruh dan air yang berasa.

Kekeruhan air disebabkan oleh zat padat yang tersuspensi, baik yang bersifat anorganik yang berasal dari tanah, pasir, pelapukan batuan dan logam maupun organik yang berasal dari pembusukan bagian dari tumbuhan atau hewan yang dapat menjadi makanan bakter. Selain menyebabkan kekeruhan air bahan organik yang mengalami pembusukan dan kontak dengan air akan menyebabkan air tersebut mempunyai rasa (Sucipto, 2019). Rasa pada air disebabkan juga oleh kandungan zat kimia yang terlarut dalam air. Air yang berasa dapat menimbulkan masalah kesehatan, air asam dapat mempengaruhi ketahanan gigi dan gangguan pencernaan. Gangguan pencernaan dapat juga disebabkan karena air yang terlalu basa. (Suyono and Budiman, 2010). Hasil penelitian (Sinatrya and Muniroh, 2019) menunjukkan kualitas fisik air minum yang tidak memenuhi syarat yakni air berbau dan berasa lebih banyak ditemui pada balita stunting.

Berdasarkan hasil analisis seperti yang terlihat Tabel 3 didapatkan tiga indikator penyebab resiko pencemaran paling tinggi yaitu (1) adanya sumur pencemar lain, seperti kotoran hewan, sampah dan genangan air pada jarak 10 meter, (2) adanya genangan air pada jarak 2 (dua) meter disekitar sumur responden masingmasing sejumlah, dan (3) adanya retakan di lantai sumur responden (Tabel 3).

Jarak sumber pencemar digolongkan menjadi dua yakni point source (lokasi mudah terdeteksi seperti leachate yang berasal dari tempat pembuangan kotoran dan sampah) dan non point source ( lokasi yang sulit untuk 
diketasui misal yang berasal dari siklus hidrologi atau industri) (Sucipto, 2019). Dalam persyaratan pembuatan sumur gali sumber pencemar yaitu kotoran hewan, sampah dan genangan air harus mempunyai jarak dari sumber air minimal 10 meter. Kotoran hewan merupakan salah satu penyebab pencemar air jenis bakteriologis/ mikrobiologis, mikroba pada jenis pencemar ini sebagian besar berasa dari tubuh manusia atau hewan yaitu feses dan urine. Tinja (feses) mengandung mikroba patogen. Air seni (urine), mengandung nitrogen, posfor, dan sedikit mikroorganisme (Mubarak and Chayatin, 2009). Aktivitas pencemar mikroba pada air akan menyebabkan gangguan kesehatan pada manusia yang mengkonsumsinya. Sampah merupakan salah satu penyebab pencemar air jenis pencemar bahan padat terlarut atau tersuspensi, jika pembuangan sampah berada dekat dengan sumber air dapat mencemari air sehingga mengurangi nilai fisik kualitas air tersebut. Air yang tercemar kemungkinan mengandung zat berbaya yang menyebabkan penyakit yang ditularkan secara tidak langsung, salah satunya adalah diare (Suyono and Budiman, 2010)

Genangan air dapat terjadi karena keadaan pada bangunan lantai sumur datar atau mempunyai kemiringan yang berlawanan arah dengan saluran pembuangan. Persyaratan pembuatan sumur, lantai harus semen, kedap air dan lebar lantai sumur mempunyai radius minimal 1 (satu) meter serta kemiringan lantai $1-5 \%$ kearah saluran pembuangan (Kementerian PUPR, 2019). Genangan air pada lantai sumur dapat menjadi tempat bersarang vektor, seperti nyamuk Aedes aegypti yang merupakan perantara atau pembawa virus dengue terhadap tubuh manusia hingga menjadi penyakit demam berdarah. Balita yang menderita penyakit infeksi seperti demam berdarah mempunyai peluang lebih besar mengalami kejadian stunting (Hamalding, Said and Nurmiati, 2020)

Persyaratan pembuatan sumur gali lantai sumur yang mengitari sumur harus dilakukan penyemenan lantai yang sempurna tidak retak dan tidak ada genangan air pada jarak 2 (dua meter) dari sumur. Lantai sumur yang retak
Tabel 4. Distribusi frekuensi kategori sanitasi penyediaan air bersih

\begin{tabular}{lllll}
\hline $\begin{array}{l}\text { Kategori } \\
\text { sanitasi } \\
\begin{array}{l}\text { penyediaan } \\
\text { air bersih }\end{array}\end{array}$ & \multicolumn{2}{l}{$\begin{array}{l}\text { Sumur } \\
\text { Gali }\end{array}$} & $\begin{array}{l}\text { Sumur } \\
\text { Pompa/Ledeng }\end{array}$ \\
\cline { 2 - 5 } & $\%$ & $\mathrm{~N}$ & $\%$ \\
\hline Tidak Baik & 0 & 0 & 0 & 0 \\
Kurang Baik & 16 & 38,1 & 16 & 33,33 \\
Baik & 26 & 61,9 & 32 & 66,67 \\
Sangat Baik & 0 & 0 & 0 & 0 \\
Total & 42 & 100 & 48 & 100
\end{tabular}

Sumber : Data Primer, 2020

dapat menyebabkan timbulnya genangan air. Genangan air sisa kegiatan rumah tangga seperti mandi dan mencuci merupakan limbah cair yang dapat menyebabkan gangguan kesehatan terhadap manusia mengingat ada banyak penyakit yang ditularkan melalui air. Namun air limbah tidak menyebabkan penyakit secara langsung karena air limbah hanya sebagai media pembawa dan di dalam air limbah terkandung mikroorganisme patogen penyebab penyakit, seperti: (1) Virus, penyebab penyakit Polio myelitis dan Hepatitis, (2) Vibrio Kolera penyebab penyakit kolera Asiatika, (3) Salmonella thyposa penyebab penyakit Thypus abdomunalis, (4) Shigella spp. penyebab penyakit disentri Basiller, (5) Askaris Spp. dan Enterbius spp. penyebab penyakit cacingan (Sucipto, 2019).

Kategori penilaian untuk sanitasi penyediaan air bersih yang dipergunakan responden diperlihatkan pada Tabel 4.

Berdasarkan Tabel 4 kategori sanitasi penyediaan air bersih yang kurang baik banyak ditemukan pada sumur gali. Sumur gali merupakan sumber air yang berada pada lapisan tanah yang relatif dekat dari permukaan tanah. Sehingga sumur gali sangat mudah terkontaminasi melalui rembesan, seperti bekas penggunaan air sumur itu sendiri (air bekas cucian dan mandi). Selain itu, sumur gali mempunyai resiko pencemaran lebih tinggi, karena terbuka (Sabanari, Joseph and Maddusa, 2017). Sumur gali dinilai kurang cukup memenuhi syarat kesehatan dibandingkan dengan sumur pompa/ledeng, sumur pompa lebih aman karena ada penutup sumur yang dapat mencegah terjadinya pencemaran pada 
Tabel 5. Hubungan sanitasi penyediaan air bersih dengan kejadian stunting

\begin{tabular}{|c|c|c|c|c|c|c|c|c|c|}
\hline \multirow{3}{*}{$\begin{array}{l}\text { Sanitasi Penyediaan } \\
\text { Air Bersih }\end{array}$} & \multicolumn{4}{|c|}{ Status gizi balita } & \multirow{2}{*}{\multicolumn{2}{|c|}{ Total }} & \multirow{3}{*}{$p$-value } & \multirow{3}{*}{$O R$} & \multirow{3}{*}{$C I(95 \%)$} \\
\hline & \multicolumn{2}{|c|}{ Kasus } & \multicolumn{2}{|c|}{ Kontrol } & & & & & \\
\hline & $\mathrm{N}$ & $\%$ & $\mathrm{~N}$ & $\%$ & $\mathrm{~N}$ & $\%$ & & & \\
\hline Tidak Baik & 0 & 0 & 0 & 0 & 0 & 0 & & & \\
\hline Kurang Baik & 21 & 46,7 & 11 & 24,4 & 32 & 35,56 & 0,047 & 2,705 & $1,103-6,635$ \\
\hline Baik & 24 & 53,3 & 34 & 75,6 & 58 & 64,44 & & & \\
\hline Sangat Baik & 0 & 0 & 0 & 0 & 0 & 0 & & & \\
\hline Total & 45 & 100 & 45 & 100 & 90 & 100 & & & \\
\hline
\end{tabular}

Sumber : Data Primer, 2020

air. Akan tetapi pada daerah atau tempat tertentu terdapat masyarakat yang memilih sumur gali karna dianggap lebih ekonomis, penggunaan sumur pompa memerlukan biaya yang cukup tinggi dalam pengadaan mesin pompa dan penggunaan tenaga listrik (Mubarak and Chayatin, 2009)

Analisis Hubungan antara Sanitasi Penyediaan Air Bersih dengan Kejadian Stunting

Berdasarkan kategori sanitasi yang telah diperoleh, maka analisis data yang digunakan adalah uji Chi-Square tabel $2 \times 2$. Adapun hasil yang didapatkan dari analisis bivariat penelitian ini disajikan dalam Tabel 5.

Hasil penelitian ini menunjukkan sebanyak 32 responden mempunyai sanitasi penyediaan air bersih yang kurang baik $(35,56 \%)$. Hasil analisis bivariat membuktikan bahwa terdapat hubungan yang signifikan antara sanitasi penyediaan air bersih dengan kejadian stunting, $p$-value pada penelitian ini $0,047(p \leq 0,05)$. Nilai OR pada penelitian ini adalah 2,705 dengan CI 95\% 1,103-6,634 . Hasil penelitian ini memperlihatkan bahwa responden yang mempunyai sanitasi penyediaan air bersih kurang baik memiliki peluang mengalami stunting 2,705 kali lebih besar dibandingkan dengan responden yang mempunyai sanitasi penyediaan air bersih baik. Berdasarkan hasil penelitian, sebagian besar responden tidak memenuhi indikator sanitasi yaitu keberadaan sumber air yang bebas dari sumber pencemar lain pada jarak 10 meter dari sumur, keberadaan genangan air dalam jarak 2 meter di sekitar sumur, serta keadaan sumur yang retak dan tidak terawat.

Sejalan dengan hasil penelitian Rita et al., (2019) menunjukkan adanya hubungan yang signifikan antara sanitasi lingkungan dengan kejadian stunting. Balita dengan sanitasi lingkungan yang kurang baik mempunyai peluang mengalami stunting 10.879 kali lebih besar dibandingkan balita dengan sanitasi lingkungan baik. Hasil penelitian Apriluana and Fikawati (2018) juga menunjukkan bahwa balita dengan sanitasi yang tidak cukup dan air tidak layak mempunyai peluang mengalami stunting masingmasing sebesar 1,37 kali dan 1,09 kali. Akses ke sanitasi yang layak dapat melindungi terhadap stunting sebesar 70,6\% (Vilcins, Sly and Jagals, 2018). Air minum yang bersih dan memadai, sanitasi layak, saluran air untuk air limbah dan pengelolaan limbah padat yang tepat adalah intervensi kesehatan ekuitas yang utama (WHO, 2018).

Kondisi lingkungan yakni kurangnya akses ke fasilitas sanitasi air bersih dan aspek jamban yang tidak memenuhi syarat sangat mempengaruhi kejadian stunting. Lingkungan yang tidak memenuhi syarat kesehatan menimbulkan terjadinya transmisi penyakit dari tinja ke mulut, sehingga timbul penyakit seperti diare, cacingan, serta enteropati lingkungan. Enteropati lingkungan merupakan kondisi gangguan subklinis yang dipercaya karena infeksi usus yang berulang sehingga menyebabkan masalah kronis penyerapan gizi karena perubahan dinding usus. Infeksi tersebut membuat gizi sulit diserap oleh tubuh, ketika kebutuhan gizi dalam tubuh tidak terpenuhi mengakibatkan energi dalam tubuh balita harus dibagi, energi yang seharusnya digunakan untuk pertumbuhan beralih untuk melakukan perlawanan tubuh menghadapi infeksi (Apriluana and Fikawati, 2018).

Penyakit infeksi berdampak negatif pada 
pertumbuhan dan gizi, dan anak-anak dengan gizi buruk mengalami kematian yang berlebihan akibat penyakit tersebut (Russell and Azzopardi, 2019). Sehingga kondisi sanitasi lingkungan yang baik dapat melindungi anak terhadap kejadian stunting (Mukaramah and Wahyuni, 2020).

Terdapat tiga variabel lingkungan yang signifikan yang berhubungan dengan prevalensi stunting yaitu sumber air minum, fasilitas sanitasi, dan pembuangan sampah. Faktor penentu stunting bersifat kompleks, maka diperlukan upaya kerja sama lintas sektor yang saling menguntungkan dalam memerangi stunting melalui intervensi yang tepat (Irianti et al., 2019). Intervensi yang tepat dalam penanganan dan penurunan stunting adalah intervensi gizi sensitif. Intervensi gizi sensitif mengintervensi terhadap penyebab stunting dilakukan dengan perbaikan sanitasi dan peningkatan penyediaan air bersih melalui sistem penyediaan air bersih berbasis masyarakat sehingga mendapat akses sanitasi yang layak dan akses air minum yang aman (Saputri and Tumangger, 2019).

Air, sanitasi, dan kebersihan tetap menjadi intervensi penting bagi kesehatan dan perkembangan anak dan merupakan pusat dari pembangunan berkelanjutan karena tiga alasan utama, yaitu: pertama, akses ke air, sanitasi, dan kebersihan adalah hak asasi manusia yang fundamental, Pemerintah telah berkomitmen untuk mencapai akses universal ke air, sanitasi, dan kebersihan melalui Sustainable Development Goals (SDGs). Kedua, air, sanitasi, dan kebersihan mencegah infeksi trachoma dan cacing pada anak-anak. Ketiga, menunjukkan efek jangka panjang air, sanitasi, dan kebersihan berpengaruh pada stunting dan gizi (Russell and Azzopardi, 2019)

Sejalan dengan penelitian Irianti et al., (2019) yang mengemukakan bahwa $21,58 \%$ dari kejadian stunting pada anak-anak usia bawah lima tahun yang berada di pedesaan dapat dicegah dengan menyediakan akses ke sumber air minum yang lebih baik dan pengelolaan sampah rumah tangga yang lebih baik. Temuan ini menguatkan bahwa air dan sanitasi adalah intervensi kunci untuk mencegah stunting.

\section{PENUTUP}

Berdasarkan hasil analisis data dan pembahasan yang telah dilakukan maka dapat disimpulkan bahwa sebaran balita yang mengalami stunting di Desa Tamanmartani paling banyak ditemukan pada kelompok usia 24-36 bulan dengan jenis kelamin perempuan. Gambaran sanitasi penyediaan air bersih kategori baik sebagian besar dimiliki oleh responden dengan balita normal, sebaliknya pada kategori kurang baik sebagian besar dimiliki oleh responden dengan balita stunting. Hasil analisis bivariate dengan uji chi-square diperoleh ada hubungan antara sanitasi penyediaan air bersih dengan kejadian stunting.

Saran bagi peneliti selanjutnya, dapat melakukan penilaian kategori kualitas air bersih secara kimia dan biologis. Bagi instansi kesehatan terkait, dapat meningkatkan peran masyarakat dengan penyuluhan masyarakat tentang pemeliharaan, perbaikan sanitasi penyediaan air bersih warga, dan memaksimalkan kegiatan monitoring sanitasi sumber air bersih masyarakat.

\section{DAFTAR PUSTAKA}

Adriany, F. et al. 2021. 'Hubungan Sanitasi Lingkungan dan Pengetahuan dengan Kejadian Stunting pada Balita di Wilayah Puskesmas Rambah', Jurnal Kesehatan Global, 4(1), pp. 17-25. doi: 10.33085/jkg.v4i1.4767.

Apriluana, G. and Fikawati, S. 2018. 'Analisis Faktor-Faktor Risiko terhadap Kejadian Stunting pada Balita (0-59 Bulan) di Negara Berkembang dan Asia Tenggara', Media Litbangkes, 28(4), pp. 247-256. Available at: https://ejournal2.litbang.kemkes.go.id/index. $\mathrm{php} / \mathrm{mpk} /$ article/view/472/537.

Dinas Kesehatan Kabupaten Sleman. 2018. Profil Kesehatan Kabupaten Sleman Tahun 2018. Yogyakarta. Available at: https://dinkes.slemankab.go.id/wpcontent/uploads/2018/09/PROFILKESEHATAN-2018-1.pdf.

Hamalding, H., Said, I. and Nurmiati, S. 2020. 'Analisis Determinan Kejadian Stunting Di 
Desa Taraweang Kecamatan Labakkang Kabupaten Pangkep', Jurnal Dunia Gizi, 3(1), pp. 9-14. Available at: http://ejournal.helvetia.ac.id/index.php/jdg/ article/download/4646/356.

Illahi, R. K. 2017. 'Hubungan Pendapatan Keluarga, Berat Lahir, Dan Panjang Lahir Dengan Kejadian Stunting Balita 24-59 Bulan Di Bangkalan', Jurnal Manajemen Kesehatan Yayasan RS.Dr. Soetomo, 3(1), pp. 1-14. doi: 10.29241/jmk.v3i1.85.

Initiatives, D. 2018. 2018 Global Nutrition Report: Shining a light to spur action on nutrition, Development Initiatives Poverty Research Ltd. Bristol, UK. doi: 10.1063/1.4759115.

Irianti, S. et al. 2019. 'The Role of Drinking Water Source, Sanitation, and Solid Waste Management in Reducing Childhood Stunting in Indonesia', IOP Conference Series: Earth and Environmental Science, 344(1). doi: 10.1088/1755-1315/344/1/012009.

Kemenkes RI. 2018. Buletin Jendela Data dan Informasi Kesehatan: Situasi Balita Pendek di Indonesia, Pusat Data dan Informasi Kementerian Kesehatan $R I$. Jakarta.

Kemenkes RI. 2020. Standar Antropometri Anak, Peraturan Menteri Kesehatan Republik Indonesia Nomor 2 Tahun 2020. Indonesia. Available at: http://hukor.kemkes.go.id/uploads/produk_ hukum/PMK_No_2_Th_2020_ttg_Standar_ Antropometri_Anak.pdf.

Kementerian PUPR. 2019. Panduan Pembangunan Perumahan dan Pemukiman Perdesaan Sumur Gali. Jakarta. Available at: https://simantu.pu.go.id/content/?id=3448.

Khulafa'ur Rosidah, L. and Harsiwi, S. 2019. 'Hubungan Status Gizi dengan Perkembangan Balita Usia 1-3 Tahun (Di Posyandu Jaan Desa Jaan Kecamatan Gondang Kabupaten Nganjuk)', Jurnal Kebidanan Dharma Husada Kediri, 6(2), pp. 24-37. doi: 10.35890/jkdh.v6i1.48.

Lalo, E., Tahu, S. K. and Bara, S. O. 2018. 'FaktorFaktor yang Berhubungan dengan Kejadian Stunting pada Balita di Wilayah Kerja Unit Pelayanan Terpadu (UPT) Puskesmas Eobobo Kupang', CHMK Midwifery Scientific Journal, 2(3), pp. 9-19. Available at: http://cyberchmk.net/ojs/index.php/bidan/article/downl oad/394/112/.

Mubarak, W. I. and Chayatin, N. 2009. Ilmu Kesehatan Masyarakat: Teori dan Aplikasi. Jakarta: Salemba Medika.
Mukaramah, N. and Wahyuni, M. 2020. 'Hubungan Kondisi Lingkungan dengan Kejadian Stunting pada Balita di Rt 08, 13 dan 14 Kelurahan Mesjid Kecamatan Samarinda Seberang 2019', Borneo Student Research, 1(2), pp. 750-754. Available at: http://journals.umkt.ac.id/index.php/bsr/art icle/download/379/388.

Rah, J. H. et al. 2015. 'Household Sanitation and Personal Hygiene Practices are Associated with Child Stunting in Rural India: A crossSectional Analysis of Surveys', BMJ Open, 5(2). doi: 10.1136/bmjopen-2014-005180.

Rahayu, B. and Darmawan, S. 2019. 'Hubungan Karakteristik Balita, Orang Tua, Higiene Dan Sanitasi Lingkungan Terhadap Stunting Pada Balita', Binawan Student Journal, 1(1), pp. 2227. Available at: http://journal.binawan.ac.id/bsj/article/view $/ 46$.

Rita, W. et al. 2019. 'Hubungan Pola Asuh dengan Kejadian Stunting (Rekomendasi Pengendaliannya di Kabupaten Lebong)', Riset Informasi Kesehatan, 8(2), pp. 140-151. doi: 10.30644/rik.v8i2.237.

Russell, F. and Azzopardi, P. 2019. 'WASH: a basic human right and essential intervention for child health and development', The Lancet Global Health, 7(4), p. e417. doi: 10.1016/S2214-109X(19)30078-6.

Sabanari, G. L., Joseph, W. B. S. and Maddusa, S. S. 2017. 'Uji Bakteriologis Air Sumur Gali Ditinjau Dari Faktor Konstruksi dan Sanitasi Lingkungan Sekitar Sumur di Kelurahan Makawidey Kecamatan Aertembaga Kota Bitung', Jurnal Kesmas, 7(4), pp. 1-8. Available

at: https://ejournal.unsrat.ac.id/index.php/kesm as/article/download/22973/22669.

Saputri, R. A. and Tumangger, J. 2019. 'Hulu-Hilir Penanggulangan Stunting di Indonesia', Jurnal of Political Issues, 1(1), pp. 1-10. doi: https://doi.org/10.33019/jpi.v1i1.2.

Sinatrya, A. K. and Muniroh, L. 2019. 'Hubungan Faktor Water, Sanitation, and Hygiene (WASH) dengan Stunting di Wilayah Kerja Puskesmas Kotakulon, Kabupaten Bondowoso', Amerta Nutrition, 3(3), pp. 164170. doi: 10.2473/amnt.v3i3.2019.164-170.

Sucipto, C. D. 2019. Kesehatan Lingkungan. Yogyakarta: Gosyen Publishing. 
Septi, K, N., Elisabeth, D, S., Ayu, F. / Sanitasi Penyediaan Air / JPPKMI 2 (1) (2021)

Suyono and Budiman. 2010. Ilmu Kesehatan Masyarakat Dalam Konteks Kesehatan Lingkungan. Jakarta: EGC.

Torlesse, H. et al. 2016. 'Determinants of stunting in Indonesian children: Evidence from a crosssectional survey indicate a prominent role for the water, sanitation and hygiene sector in stunting reduction', BMC Public Health, 16(1), pp. 1-12. doi: 10.1186/s12889-016-3339-8.

Vilcins, D., Sly, P. D. and Jagals, P. 2018. 'Environmental Risk Factors Associated with Child Stunting: A Systematic Review of the
Literature', Annals of Global Health, 84(4), pp.

551-562. Available

at:

https://www.ncbi.nlm.nih.gov/pmc/articles/

PMC6748290/pdf/agh-84-4-2361.pdf.

WHO. 2018. Reducing Stunting In Children: Equity considerations for achieving the Global Nutrition Targets 2025, World Health Organization. Genevq. Available at: https://apps.who.int/iris/bitstream/handle/1 0665/260202/9789241513647-

eng.pdf?sequence $=1$. 